\title{
Niche Construction as a Theoretical Tool in the Ethnographic Analysis from a Naturalistic Perspective
}

\author{
Crivos Marta $A^{1^{*}}$, Lamas Susana Gisela ${ }^{2}$ and Dressino Vicente ${ }^{2}$ \\ ${ }^{1}$ Laboratory of Research in Applied Ethnography (LINEA), Facultad de Ciencias Naturales y Museo (UNLP), Buenos Aires, \\ Argentina \\ ${ }^{2}$ Laboratory of Research on Ontogeny and Adaptation (LINOA), Facultad de Ciencias Naturales y Museo (UNLP), Buenos \\ Aires, Argentina
}

\begin{abstract}
In this work, we intend to move discussion forward on the heuristic role of the concept of niche construction for the review of the human/environment dichotomy by considering the interaction between biotic and abiotic components in specific environments. We will examine an ethnographic case study which explores the perception of the landscape and its use by different human groups (Mbyá-Guaraní and descendants of European colonos) that inhabit a territory with common biophysical features: The Paranaense forest in Northeastern Argentina. According to these narratives, the consideration of the monte is closely related to the modes of interaction with the natural environment resulting from their daily subsistence practices. This comparative study shows how the monte has been differentially built and valued in the course of this interaction.
\end{abstract}

\section{Keywords}

European colonos, Mbyá Guaraní communities, Niche construction, Paranaense forest, Subsistence practices

\section{Introduction}

Our research discusses the almost unexplored theoretical potential of the new biological theories for the understanding of certain issues in humans. In this sense, we intend to highlight the naturalistic perspective through which humans are modestly conceived as one of the many species that inhabit our planet. Therefore, we explore the importance of a useful conceptual tool from the field of biology for ethnographic studies, namely the notion of niche construction.

The theories belonging to the Darwinian tradition (Darwin's theory of evolution, neo-Darwinism and synthetic theory of evolution) conceive individuals as passive subjects exposed to external forces called selective pressures, which mould organisms and populations either cumulatively - by selecting certain traits - or eliminative - by discarding others. Furthermore, Bonduriansky and Day [1] argue that extended inheritance challenges the key assumptions of neo-Darwinism and pushes us to redefine evolution as "changes in all hereditary traits, whether genetic or non-genetic". At present, however, the extended evolutionary synthesis has a relational approach, understanding individuals as active organisms in relation to their environment.

\section{The Concept of Niche Construction}

We believe that in order to understand the niche construction proposal, we must first clarify the relationship between different related terms: Habitat, ecological niche and niche construction. Habitat refers to the physical space where an organism lives. This concept includes topography (hollow, mountain, swamp, etc.), support organisms (grass, fallen trunks, etc.), the microclimate, the soil and the rest of the living beings [2-4]. On the other hand, ecological niche is a term closely related to habitat and it describes a species or population in an ecosystem. This concept encompasses the resources of the environment, the adaptations of organisms and how the environment and adaptations are related [2,5-7]. In summary, the ecological niche represents the function of the organism in a specific

*Corresponding author: Crivos Marta A, Laboratory of Research in Applied Ethnography (LINEA), Facultad de Ciencias Naturales y Museo (UNLP), Calle 65 \#833, Piso 8vo, Departamento C (C.P. 1900), La Plata, Buenos Aires, Argentina, Tel: +54-221-4517329

Accepted: October 22, 2019

Published online: October 24, 2019

Citation: Crivos MA, Lamas SG, Dressino V (2019) Niche Construction as a Theoretical Tool in the Ethnographic Analysis from a Naturalistic Perspective. Insights Anthropol 3(2):201-206 
environment (carnivore, herbivore, etc.). Finally, the niche construction theory arises in biology as a proposal related to the ecological niche but from a procedural approach. It assumes that organisms play an active role modifying their environment and that of other organisms. We will briefly explain the theoretical development of these concepts, taking these conceptual differences into account.

The classical notion of ecological niche is in line with the Darwinian theories, conceiving organisms as passive subjects. First proposed by Hutchinson [5], it was characterized as the $n$-dimensional hyper volume of conditions under which organisms develop and reproduce. This ecological concept comprises the partially overlapping notions of niche and habitat.

Subsequently, Lewontin [8,9] introduced a different approach for understanding the intimate organism/environment relationship. He conceived it as a dynamic process in which the environment poses problems to organisms, only leaving those offspring best equipped to solve the problems; this process is metaphorically understood as an adaptation. Influenced by this new perspective, Odling-Smee [10], who openly stated his intention of developing it theoretically and empirically, proposed a novel concept, the niche construction, in which the organism itself generates the necessary environmental conditions to complete its life cycle.

As claimed by Odling-Smee, et al. [11], most literature makes reference to the evolutionary impact of environmental modification on organisms, but it rarely mentions the changes driven by an organism in the environment. Hence, the need to account for this interaction gave rise to the notion of niche construction, the process through which organisms modify their environments, thereby determining the pressures on themselves and their offspring. In this sense, a dynamic is established in which parents exploit and modify a niche, their offspring thus "inheriting" a new niche that does not correspond exactly with the one originally created by their parents. This constant dynamic varies in every generation according to the interaction between the environmental changes made by the parental generation and associated environmental changes (biotic or abiotic).

Previous research has shown that niche construction encompasses an area ranging from physiological changes in metabolism to changes in daily activities, including the search and the consumption of new types of food $[11,12]$. For instance, animals modify their environment and that of non-related populations through different activities, such as digging burrows, building dams that affect other ecosystems (e.g. beavers), making nests and webs, aerating the soil, carrying out photosynthesis, etcetera [11-13]. It is important to stress that in the notion of niche construction, the term "niche" refers to the sum of the natural pressures experienced by a certain population, while "construction" refers to altering the environmental pressures, either by modification of the physical environment or through habitat choice [11].
Having a similar approach, Laland, et al. [14] understand the niche construction as the process by which organisms actively modify their own evolutionary niches and those of other species. Among other things, this concept allows for a better understanding of both the interrelationship between changes on a small scale (organisms) and at larger scales (populations or species) and the evolutionary impact it entails. Therefore, it has been proposed as a new mechanism for speciation. Indeed, the development of many organisms and the transmission of traits through generations are critically related with the construction of environments by ancestral organisms [14-16]. The most likely paradigmatic example is represented by molecular oxygen on Earth that would have originated from the photosynthesis of the ancestral cyanobacteria, which managed to build a favourable system for the development and evolution of aerobic life forms through the photosynthesis.

\section{The Concept of Niche Construction in An- thropology}

Anthropologically, niche construction has been analysed from different angles. Laland and O'Brien [17] propose evolutionary models suggesting close relationships between niche construction and genetics. Other authors propose a socio-cultural perspective of niche construction [18-20] that involves a much more extensive timeframe than the one analysed in this article.

According to Schultz [21], the notion of niche construction should be regarded as if it operates on multiple scales including the appropriate theoretical tools for the study of the behaviours of niche construction in each one. In general, research was carried out by bioarchaeologists where the modifications by humans of the biotic and abiotic environments were on large timescales. However, in this article we will consider a microscale analysis typical of ethnographic studies. In this way we will attempt to operationalize the term niche construction by reference to empirical-analytic units (the domestic unit). This will permit the description of human environment interactions involved in the subsistence of the domestic group.

Based on the aforementioned and in line with the position of Fuentes [22-24] and Downey [25], we believe that the concept of niche construction is a useful instrument for the recognition and consideration of the interspecific relationships that shape particular environments. The characterisation of lifestyles of human populations with different settlement histories provides valuable information about the web of interactions that makes possible the existence, coexistence and subsistence of both biotic and abiotic entities in specific environments. This perspective can be useful for the characterisation and prediction of changes in the environment shaped by the activities and the interactions of its participants. As a descriptive instance of anthropological research, the ethnographic approach especially allows retrieving information about the interactions that link individuals of our species to other components of the environment for the resolution of daily life problems. It also helps to retrieve information about factual and reg- 
Citation: Crivos MA, Lamas SG, Dressino V (2019) Niche Construction as a Theoretical Tool in the Ethnographic Analysis from a Naturalistic Perspective. Insights Anthropol 3(2):201-206

ulatory components of human activity that involves the interaction with other species.

In this work, we will analyse the contribution that the concept of niche construction can make to the anthropological discussion by examining an ethnographic case study which explores the perception of the landscape and its use by different human groups.

\section{Case Study}

As previously explained, we will examine an ethnographic case study which explores the perception of the landscape and its use by different human groups inhabiting a territory with common biophysical characteristics - the Paranaense forest in the northeast of Argentina. Consequently, our work will be based on a research carried out by Crivos, et al. [26-28] which describes and accounts for different forms of domestication of the monte (forest) through the narratives of MbyáGuaraní inhabitants and descendants of European colonos, both currently established in the region of the Cuña Pirú Valley in the Province of Misiones, Argentina.

The fieldwork was carried out between the mid-1990s and the beginning of 2000. Two Mbyá Guaraní communities -Kaaguy Poty and Yvy Pytá-located at coordinates $27^{\circ}$ $11^{\prime} 0^{\prime \prime} \mathrm{S}$. and $54^{\circ} 57^{\prime} 0^{\prime \prime} \mathrm{W}$. and the families of colonos established in surrounding areas were studied. These Mbyá communities were composed of 258 people - according to the 1996 health census. The first of them - Kaaguy Poty-had a total of 139 inhabitants distributed in 26 families and 18 homes, while the second one -Yvy Pytá-, 119 inhabitants distributed in 22 families and 20 homes. As regards the descendants of European colonos, four families were studied, which were settled in an area near the territory. The term colonos is given to the descendants of European and Asian immigrants who came to Argentina after the second half of the $19^{\text {th }}$ century in order to exploit the land transferred by the government for the development of agriculture and farming activities. During that period, successive fieldworks were conducted to obtain relevant information regarding the characterisation of spaces where activities oriented towards obtaining and producing natural resources are developed.

The information on which this work is fundamentally based comes from interviews (semi-structured and open-ended) to adult individuals of both genders touted as representative members of each domestic unit as well as from systematic observations in different spaces where each group activities goes by. While possible, researchers also accompanied people throughout their daily activities. The informal nature of the interactions with interviewees during this process allowed for spontaneous comments and observations regarding the most outstanding aspects of nearby spaces.

According to the narratives gathered, the consideration of the monte by both groups is closely related to their modes of interaction with the natural environment resulting from their daily subsistence practices. From a comparative ethnographic exploration, it can be clearly seen how the forest is differentially built and valued in the course of this interaction.

On the other hand, the notion of "domestic unit" will be considered as a theoretical category given its importance for this analysis. This term is operationally defined as the complex unit that includes a social component - group of people that share the residence-and a spatial component - the physical space where they live-articulated by a set of activities that are relevant to the subsistence of the group and that are done, partially or totally, in this scope [29]. Thus, the adjective "domestic" - from the Latin domesticus or "belonging to the household"-entails a space that extends beyond the concept of house as a building, since it refers to the area delimited by the daily subsistence activities of the domestic group. This space is, therefore, recognized and differentiated by the Mbyá, who do not consider its proximity to the house when demarcating the areas of the monte, but the particular modes of intervention and soil use on a much larger and varied scale. On the other hand, the pathways created by the different members of these communities in the physical space can also be observed as a result of clearing their own paths depending on their needs and interests (for example, while gathering food or growing medicinal plants). This is reflected in the following excerpt from an interview:

[We do not have the property title]. (...) That's why we cannot definitively recover the land for us. That's why we are worried. We want to be marked, we follow that line. We do not plant much, but we walk a lot, we have to walk through the monte. We do not take much land, but we need (it) to look for resources - that's our idea.

In the case of the Mbyá-Guaraní communities, the forest is described as a non-homogeneous habitat divided into different areas, including: ka'aguy ete (the primary forest, where most trees are tall); ka'aguy karape (the low forest, consisting of shrubs and small trees); kokue (chacras, or small farms); and kokue re (capuera, which means "what once was a farm", usually characterised by secondary colonising flora, shrubs, and small trees, typical of disturbed environments). These terms reaffirm the sequential and evolutionary nature of the monte by referring to the different stages in the transformation of a single space as a result of human intervention [30]. However, this sequencing reflects a differential environmental intervention. For instance, the Mbyá only grow certain species of plants in the chacras and intervene to prevent other plants or animals from hindering their growth. In the capuera, they also intervene at some stage, but also allow plants to grow naturally without further intervention. There is also an intervention in the low and the primary forests, since they need to search for resources, but this intervention is smaller than in the previous cases.

Thus, two issues can be observed: first, the "domestic" aspect extends to the monte in a gradual modification, and second, in line with the first aspect, the differential mode of intervention is associated with different levels of biodiversity in the physical spaces. However, the Mbyá-Guaraní 
communities' passing from a nomadic to a sedentary life implies a selective modification of the environment that entails the extension or the loss of the biodiversity, since these modifications also affect its inhabitants' lifestyles. For instance, according to the interviewees, some resources may become more accessible - such as the ones grown in the chacras-while others, increasingly difficult or impossible to obtain - for instance, certain animals they hunt in the forest.

In contrast, when the forest had not been cleared yet, the Mbyá had a nomadic lifestyle, moving freely through the monte. Thus, they were able to obtain resources from any area of the forest, without being forced to strongly intervene in a small, specific area. At present, less than $7 \%$ of the original cover of the Paranaense forest in Brazil, Argentina and Paraguay remains [31].

More plants were grown before. We used to go to the monte more often. Hearts of palm and honey were gathered. It was common to walk through the monte. Now they do not want to go to the monte anymore. They know that they will get lost, so they don't go anymore. They work here in the colonia. They do jobs there (member of Ka'aguy Poty community, 1996).

Now we have a little more work. Years ago, our grandparents live a different kind of life, a quiet life. Nobody bothered them. They lived in the monte and there were no illnesses. It was nice, but things have changed. It is not like before. We changed a little. This is not good. This is not better than before (member of Yvy Pytã community, 1996).

In this regard, the Mbyá as a group interact with their environment. They form and transform the environment, gradually extending their domestic unit through different modes of intervention (chacras, capueras, etc.). However, the environment is also modified individually by the Mbyá when clearing their own paths along their journey, for example, by growing medicinal plants in the soils they found more suitable for cultivation or more readily available to each family member. In turn, this individual environmental intervention modifies the life of each individual and of the people around him. The same situation applies to the food and other resources obtained from the monte.

(...) Cemeteries are in the monte. It was always like that, because we, indigenous people, cannot have our cemeteries next to our home. They must be a little bit farther away, so the monte is a good place. The spirits...it must be the pai, he is always who must know. He knows where (member of Yvy Pytã community, 1996).

Through the different narratives, the monte has been described as the entity which provides the Mbyá with food and a sense of identity and continuity with their ancestors. Being the provider of essential things, it must therefore be respected and preserved.

In that same environment, other human groups - the colonos-coexist, which settled in these lands through immigration from several European countries. They engaged in agriculture in a territory with climatic and ecological fea- tures which greatly differ from those in their places of origin. These colonos were given land by the Government for their agricultural expansion, which was carried out without any planning, gradually deforesting the forest. Amable, et al. [32] highlights the importance of family farming and cooperatives in the colonisation process, the Government allowing for land ownership over land leasing due to the political need to populate the territory.

For this reason, the European colonos' conception of the monte differs radically from that of the indigenous peoples. In principle, the monte is seen by the settlers as an obstacle to their agricultural activity. In their narratives, they mainly make reference to the forest in relation to the economic history of the area, which successively - and sometimes simultaneously-describes different landscapes that are formed from agricultural and livestock practices. These evoked landscapes are embodied in traces indicating a prosperous past, since the market-oriented agricultural activity of the colonos was encouraged at times by excellent economic possibilities. However, the swings in the promotion policies of different crops generated uncertainty among the settlers and their children, becoming sceptical with regard to their future as agricultural producers. Despite a discouraging present, "current colonos" continue to thank their parents for inculcating work behaviours in the farms, while the new generations project their lives outside the rural area and their natural scenery, the monte.

In this relationship, the colonos understood the monte as an obstacle to carry out their agricultural and livestock practices, so they faced the need to "clearing" or "weeding" the forest. In this sense, the monte is seen as a unit, aspect that can be observed in the excerpts from some accounts of "current colonos" who use the words monte and capuera as synonyms.

\section{Q: Have you grown this pasture or is it natural?}

A: There is no pasture here...more weed in the capuera, weeds.

\section{Q: Are the weeds in the capuera good for cattle?}

A: Some of them, yes. They eat as if it is from the monte, from de capuera [27].

Nor do they acknowledge that what grows there is no longer the same monte.

(...) And this is natural monte. This area here is a natural montecito, it was never cut. Those two were cleared and, then, grew back. After many years, the same grows back, as the little forest there [27].

(...) [It was cleared] to make meadows, but as no plants are grown, the monte grows back [27].

Therefore, the domestic unit of the colonos is much smaller than that of the Mbyá-Guaraní peoples, since their activities take place in the physical space of their house and the farm. They consider that, far from being a source of resources, what lies beyond their farm only hinders the development of other resources. 
Citation: Crivos MA, Lamas SG, Dressino V (2019) Niche Construction as a Theoretical Tool in the Ethnographic Analysis from a Naturalistic Perspective. Insights Anthropol 3(2):201-206

In the colonisation proposal, deforestation emerges as a condition for agricultural and livestock practices which are analogous to those that the European settlers carried out in their home countries. However, this treatment of the environment not only modified a great part of the lifestyle of the settlers, but also of other human groups and biotic and abiotic components of the territory.

\section{Discussion and Potential Contributions}

In this case study, we intended to succinctly show the development of different lifestyles in a given environment, and how a micro-scale modification can also have a large-scale impact, causing other effects on the life styles of current populations. These changes also condition future populations, since descendants "inherit" a niche that is different from their ancestors'. In turn, the latter also modify the environment, thereby successively co-creating populations and habitats. So, and in agreement with Bird, et al. [33], our analysis suggests that the emergent properties of human-environment interaction in a domestic scale shape landscapes and ecological communities.

Along with other species, the Mbyá have been co-creating the different setting recognized in the monte over generations. The European settlers have also recreated the habitat from their home countries, trying to develop an agricultural and livestock activity by means of techniques used for generations in their places of origin. They modified the environment and, in turn, the environment moulded them as well by practically discarding their original conception about farming practices.

In this regard, according to one of the interviewees, the Province of Misiones, Argentina, is no longer an agricultural and livestock province. In fact, politicians deem it as a territory suitable for electric power, industry, and tourism undertakings. In this context, the monte and the beauty of the landscape (in the sense of scenery, not scenario) acquire a new value: The preservation of its natural conditions in conjunction with daily activities, which will allow a new economic output: Agritourism. Therefore, the monte is no longer seen by the colonos as the area to be "colonised" but as the space to be "preserved".

Finally, regarding the concept of niche construction, two basic types of strategies can be summarized. On the one hand, the Guaraní peoples are linked to the forest through an action of coexistence, that is, a non-destructive one. Therefore, through different scales of environmental intervention, the forest becomes an extension of their domestic unit. On the other hand, the settlers build another type of niche by destroying the previous one (deforestation) for agricultural and livestock production. In this case, the forest becomes an obstruction for their domestic unit. Both processes modify the niches descendants will deal with, either by coexisting with the environment (Guaraní peoples) or by impoverishing it until becoming almost infeasible (settlers). In any case, the chances of livelihood for future generations can become predictable. The implications derived from these processes regarding other biotic and abiotic components of the system are yet to be explored.

\section{References}

1. Bonduriansky Russell, Trot Day (2018) Extended heredity: A new understanding of inheritance and evolution. Princeton University Press.

2. Udvardy MFD (1959) Notes on the ecological concepts of habitat, biotope and niche. Ecology 40: 725-728.

3. Rejmanek M, Jenik J (1975) Niche, habitat, and related ecological concepts. Acta Biotheor 100-107.

4. Morris DW (2003) Toward an ecological synthesis: A case for habitat selection. Oecologia 136: 1-13.

5. Hutchinson G Evelyn (1957) "Concluding remarks". Cold Spring Harbor Symposia on Quantitative Biology 22: 415-427.

6. Whittaker RH, Levin SA, Root RB (1973) Niche, habitat, and ecotope. The American Naturalist 107: 321-338.

7. Pocheville $A$ (2015) The ecological niche: History and recent controversies. In: Thomas Heams, Philippe Huneman, Guillaume Lecointre, et al. Handbook of evolutionary thinking in the sciences. Springer, 547-586.

8. Lewontin Richard C (1982) "Organism and environment". In: Henry C Plotkin, Learning, development and culture. Wiley, New York, 151-172.

9. Lewontin Richard C (1983) "Gene, organism and environment". In: Derek S Bendall, Evolution from Molecules to Men. Cambridge University Press, Cambridge, 273-285.

10. Odling-Smee, F John (1988) "Niche constructing phenotypes". In: Henry C Plotkin, The role of Behavior in Evolution. MIT Press, Cambridge, 73-132.

11. Odling-Smee, F John, Kevin Laland, et al. (2003) Niche construction: The neglected process in evolution. Princeton University Press, Oxford.

12. Odling-Smee, F John, Kevin Laland, et al. (1996) "Niche construction". American Naturalist 147: 641-648.

13. Odling-Smee, F John, David Erwin, et al. (2013) "Niche construction theory: A practical guide for ecologists". Q Rev Biol 88: 4-28.

14. Laland Kevin, Blake Matthews, Marcus W Feldman (2016) "An introduction to niche construction". Theory Evol Ecol 30: 191-202.

15. Badyaev, Alexander V, Tobias Uller (2009) "Parental effects in ecology and evolution: Mechanisms, processes and implications". Philos Trans R Soc B 364: 1169-1177.

16. Sultan Sonia E (2015) Organism \& environment: Ecological development, niche construction and adaptation. Oxford University Press.

17. Laland Kevin N, Michael J O'Brien (2011) “Cultural niche construction: An introduction". Biol Theory 6: 191-202.

18. Andersson Claes, Anton Tornberg, Petter Tornberg (2014) "An evolutionary developmental approach to cultural evolution". Current Anthropology 55: 154-174.

19. Ellis Erle C (2015) "Ecology in an anthropogenic biosphere". Ecol Monogr 85: 287-331.

20. Ellis Erle C, Nicholas R Magliocca, Chris J Stevens, et al. (2018) "Evolving the anthropocene: Linking multi-level selection with long-term social-ecological change". Sustain Sci 13: 119-128.

21. Schultz Emily A (2015) "Niche construction and the study of culture change in anthropology: Challenges and prospects". INTER disciplina 3: 131-159.

22. Fuentes Agustin (2015) "Integrative anthropology and the hu- 
man niche: Toward a contemporary approach to human evolution". American Anthropologist 117: 302-315.

23. Fuentes Agustin (2016) "The extended evolutionary synthesis, ethnography, and the human niche: Toward an integrated anthropology". Current Anthropology 57: 13-26.

24. Fuentes Agustin (2017) "Human niche, human behaviour, human nature". Interface Focus 7: 1-13.

25. Downey Greg (2016) "Being human in cities: Phenotypic bias from urban niche construction". Current Anthropology 57: S52-S64.

26. Crivos Marta, Maria Rosa Martinez (2000) "Cultural stories - natural stories. Mobility and landscape in the mbya-guarani narrative". Presentation at the XI International Oral History Conference (IOHA), Proccedings XI International Oral History, Conference Vol. III, Istanbul, Turkey, 1265-1269.

27. Crivos Marta, Maria Rosa Martinez, Maria Leila Pochettino (2002) "Win and lose the mountain. The narrative about the environmental change among the inhabitants of the rural area of the municipality of aristobulo del valle (Misiones, Argentina)". Presentation at the XII International Oral History Association, South Africa.

28. Crivos, Marta A, Maria Rosa Martinez, Maria Leila Pochettino, et al. (2007) "Pathways as 'Signatures in Landscape': Towards an ethnography of mobility among the mbya-Guarani (Northeast- ern Argentina)". J Ethnobiol Ethnomed 3: 1-35.

29. Crivos Marta, Maria Rosa Martinez (1996) "The strategies against the disease in molinos salta, argentina. A proposal for the survey of empirical information in the domain of ethnobiology". Presentation at Contributions to Latin American Physical Anthropology, IV Simposio de Antropologia Fisica "Luis Montane", Instituto de Investigaciones Antropologicas - UNAM/Museo Antropologico Montane, Universidad de La Habana, Spain.

30. Pochettino Maria Leila, Maria R Martinez, Marta A Crivos (2002) "Landscape domestication among two mbya-guarani communities of the province of misiones, argentina". In: John R Stepp, Felice S Wyndham, Rebecca K Zarger, Ethnobiology and Biocultural Diversity. Proceedings of the $7^{\text {th }}$ International Congress of Ethnobiology, University of Georgia Press, 696-704.

31. Galindo-Leal Carlos, Ibsen de Gusmao Camara (2003) The atlantic forest of south america: Biodiversity status, threats and outlook. Island Press, Washington DC, USA.

32. Amable María A, Karina Dohman, Lilinan M Rojas (1996) Missionary history. An integrative approach. ediciones montoya. Centro de Investigaciones Historicas "Guillermo Furlong", Posadas, Argentina.

33. Bird Douglas W, Rebecca Bliege Bird, Brian F Codding (2016) “Pyrodiversity and the anthropocene: The role of fire in the broad spectrum evolution". Evol Anthropol 25: 105-116.

DOI: $10.36959 / 763 / 503$

Copyright: (C) 2019 Crivos MA, et al. This is an open-access article distributed under the terms of the Creative Commons Attribution License, which permits unrestricted use, distribution, and reproduction in any medium, provided the original author and source are credited. 